\title{
CD133 expression may be useful as a prognostic indicator in colorectal cancer, a tool for optimizing therapy and supportive evidence for the cancer stem cell hypothesis: a meta-analysis
}

\author{
Yang Zhao ${ }^{1,2, *}$, Jing Peng ${ }^{1, *}$, Enlong Zhang ${ }^{1}$, Ning Jiang ${ }^{2}$, Jiang Li $^{1}$, Qi Zhang ${ }^{1}$, \\ Xuening Zhang ${ }^{1}$, Yuanjie Niu ${ }^{2}$ \\ ${ }^{1}$ Department of Radiology, The Second Hospital of Tianjin Medical University, Tianjin 300211, China \\ ${ }^{2}$ Sex Hormone Research Center, Tianjin Institute of Urology, Tianjin 300211, China \\ *These authors have contributed equally to this work
}

Correspondence to: Xuening Zhang, e-mail: luckyxn@qq.com Yuanjie Niu, e-mail: niuyuanjie68@126.com

Keywords: cancer stem cell, tumor recurrence, tumor genesis, CD133, meta-analysis

Received: August 18, 2015 Accepted: December 08, 2015

Published: January 28, 2016

\section{ABSTRACT}

We performed a meta-analysis of CD133-related clinical data to investigate the role of cancer stem cells (CSCs) in the clinical outcomes of colorectal cancer (CRC) patients, analyzing the effectiveness of various therapeutic strategies and examining the validity of the CSC hypothesis. For 28 studies (4546 patients), the relative risk (RR) to survival outcomes associated with $C D 133^{+}$CRCs were calculated using STATA 12.0 software. Pooled results showed that CD133 ${ }^{\text {High }}$ patients had poor 5-year overall survival (RR 0.713, 95\% CI 0.616-0.826) and 5-year disease free survival (RR 0.707, 95\% CI 0.602-0.831). Both associations were consistently observed across different races, research techniques and therapeutic strategies. In a subgroup receiving adjuvant therapy, $\mathrm{CD} 133^{\text {Low }}$ patients achieved significantly better survival than $\mathrm{CD} 133^{\text {High }}$ patients. The findings suggest that CD133 could serve as a predictive marker of poor prognosis and treatment failure in CRC. CD133 $3^{\text {Low }}$ patients could benefit from adjuvant treatments, while CD133 ${ }^{\text {High }}$ patients should be given novel treatments besides adjuvant therapy. Our results also provide evidence in support of the CSC hypothesis.

\section{INTRODUCTION}

Cancer stem cells (CSCs), also called tumorinitiating cells, are a small subpopulation of multipotent cancer cells with the capacity to self-renew $[1,2]$. According to the CSC hypothesis, these stem-like cells play a pivotal role in tumorigenesis, metastasis and relapse [1-4]. Previous work showed that only CSCs could reconstitute tumors with similar histopathological characteristics to the primary cancer, whereas non-stem cancer cells failed to effect tumor initiation $[1,5,6]$. Additionally, cancer stem cells were shown to be involved in the process of tumor invasion, metastasis and resistance to conventional therapy, which were underlying factors in tumor recurrence and treatment failure [7-9].

To the best of our knowledge, the CSC hypothesis has primarily been tested via in vitro assays or murine transplantation experiments [9-11]. Clinical evidence of tumor formation by CSCs in humans, although difficult to observe, would further validate the CSC hypothesis. Through a comprehensive meta-analysis of published CSC-related research, we evaluated whether current clinical evidence supported the CSC hypothesis.

Several molecular biomarkers have been used in clinical trials to define the existence of CSCs, including CD133, CD44 and ALDH1 [12, 13]. Based on the presence or absence of CD133, tumor cells were divided into two categories: $\mathrm{CD}_{133^{+}}$and $\mathrm{CD} 133^{-} . \mathrm{CD} 133^{+}$ tumor cells isolated from postoperative specimens exhibited stem-like properties, whereas CD133 tumor cells did not $[14,15]$. Furthermore, CD133 was expressed uniquely by stem-like cells within tumors, but was rapidly down-regulated in their progeny, indicating that $\mathrm{CD} 133^{+}$tumor cells could be regarded as CSCs [15-24]. As a universally recognized biomarker of CSCs, CD133 has been extensively utilized to 
identify and isolate CSCs in a variety of human tumors, including brain tumors, prostate tumors, pancreatic adenocarcinomas, colorectal carcinomas, hepatocellular carcinomas, melanomas, breast cancers, lung cancers, laryngeal carcinomas, and osteosarcomas [6, 15, 25-28].

Previous studies have attempted to evaluate the role of $\mathrm{CD} 133^{+}$tumor cells with respect to clinicopathological features [29-42]. Several studies suggested that a high number of $\mathrm{CD} 133^{+}$tumor cells contributed to early lymph node metastasis, advanced $\mathrm{T}$ stages, and poorly differentiated tumors [34-37]. Consistent with those findings, CD $133^{+}$tumor cells showed greater resistance to postoperative treatment, and increased CD133 expression was observed in residual cancer cells after adjuvant therapy (AT) [41]. Even with radical resection, patients expressing high levels of CD133 were found to have significantly poorer survival than those with lower expression levels [37, 38]. These results were demonstrated in a disease model of colorectal cancer (CRC), which has a high incidence of recurrence and mortality [33, 42], although results from other studies were inconclusive $[39,40]$. The meta-analysis described in the current work attempts to clarify the clinical value of CD133 expression in CRC patients.

Currently, CRC is the third most common cancer in the world, accounting for $10 \%$ of the global cancer burden $[43,44]$. In the developed world, the high incidence of metastasis and recurrence following resection contributes to patient death in approximately one-third of cases $[45,46]$. As described above, the presence of cancer stem cells may be correlated with a higher rate of treatment failure and tumor recurrence. A timely systematic review that comprehensively analyzes clinical trials measuring CD133 expression in CRCs could delineate the clinical importance of CSCs in therapeutic resistance and tumor regrowth. This work would provide not only useful information for association.

\section{RESULTS}

\section{Study selection and characteristics}

The study selection procedure is outlined in Figure 1. Following an extensive keyword search and analyses of article content and relevance, 28 published studies with a total of $4546 \mathrm{CRC}$ cases that fulfilled all inclusion criteria were included in the present meta-analysis. All included studies were case-controlled. Based on CD133 expression level, patients from all the studies were divided into two subgroups: patients with high CD133 expression levels (levels above the cut-off value) were classified into the CD133 ${ }^{\text {High }}$ subgroup, and patients with low CD133 levels were classified into the CD133 ${ }^{\text {Low }}$ subgroup. Overall, 23 studies comprising $1157 \mathrm{CD} 133^{\text {High }}$ patients and 2344 CD133 ${ }^{\text {Low }}$ patients were included in the analyses of overall survival (OS), while 15 studies including 533 CD133 $3^{\text {High }}$ patients and $1087 \mathrm{CD} 133^{\text {Low }}$ patients provided relevant outcomes of disease free survival (DFS).

The useable data and main characteristics of each article are summarized in Table 1. Eight studies were performed in western countries, and 20 in Asia. Eighteen articles enrolled over 100 patients while the other 10 studies had relatively smaller sample sizes. Four studies measured CD133 expression levels by PCR and 24 studies used immunohistochemistry (IHC) methods. All patients received surgical treatment. Eleven articles evaluated cancer survival and recurrence in patients treated with further postoperative adjuvant therapy including radiotherapy, chemotherapy and the combination of radiotherapy and chemotherapy (AT subgroup). Patients in another six studies received neither chemotherapy nor radiotherapy after surgery (non-AT subgroup).

\section{Publication bias}

Based on the Begg's funnel plots, no evident asymmetrical shapes existed in either the OS or DFS analyses (Figure 2). Meanwhile, Begg's $P$ values for OS and DFS were 0.083 and 0.553, respectively. These findings showed no evidence for obvious publication bias among the included studies, indicating that publication bias was not a potential source of heterogeneity in the prognostic factors.

\section{Quantitative data synthesis}

Using methods described previously, forest plots were performed to estimate the association between CD133 and prognostic parameters. As shown in Figure 3, the relative risk values for OS and DFS were $0.713(95 \%$ CI: 0.616-0.826) and 0.707 (95\% CI: 0.602-0.831), respectively. The pooled analysis showed that CD133 expression was highly correlated with lower OS and DFS rates. Based on $P$ value $>0.05$ and $I^{2}<50 \%$, notable heterogeneities between these studies likely existed, and the random-effect model was used to calculate the RRs of OS and DFS.

\section{Sensitivity and subgroup analyses}

Since statistically significant heterogeneity existed between the studies, further subgroup analyses were stratified by ethnicity, research techniques and therapeutic strategies. Table 2 presents the results of subgroup analysis related to the association between CD133 expression and OS or DFS. Subgroup analyses confirmed that high CD133 levels indicated a significantly poorer prognosis as compared to low levels. Ethnicity, sample size, and research technique (IHC vs. PCR) did not significantly influence the prognosis value of CD133 (Figures S1-S3). In subgroups with or without adjunctive therapy, CD133 ${ }^{\text {High }}$ patients had poorer clinical outcomes as compared to CD133 ${ }^{\text {Low }}$ patients (Figure 4). 


\section{DISCUSSION}

\section{Principle findings of a CSC marker based on clinical trials}

In the past decade, CSCs have drawn widespread attention because of their potential roles in tumorigenesis, tumor maintenance, spread and relapse. CD133 tumor cells, which can be regarded as CSCs, give rise to cells with the same phenotype as the original tumor [14, 15, 28]. As compared to non-CSCs within tumors, CSCs are more resistant to radiotherapy and chemotherapy, and may survive these treatments to generate new lesions $[47,48]$. Therefore, specific products expressed by CSCs, like CD133, may represent useful targets for clinical evaluation of tumors.

Many groups have evaluated the association between $\mathrm{CD}_{133}{ }^{+} \mathrm{CSC}$ and the clinical and pathological features of CRC patients, with conflicting results [40, 49-75]. In this article, we systematically analyzed published clinical data and attempted to resolve the discrepancies among these papers in order to elucidate the potential clinical relevancy of CD133 and examine the validity of the CSC hypothesis. We found that CD133 levels could provide clinically relevant prognostic information for CRC patients and could assist in the optimization of therapeutic strategies. Additionally, the prominent impact of $\mathrm{CD} 133^{+}$tumor cells on tumor relapse and treatment failure rates provides further evidence in support of the CSC hypothesis.

\section{Clinical relevancy of CSC marker CD133}

Several studies reported that CD133 expression was significantly correlated with histological parameters, such as tumor budding, vascular invasion, and the presence of
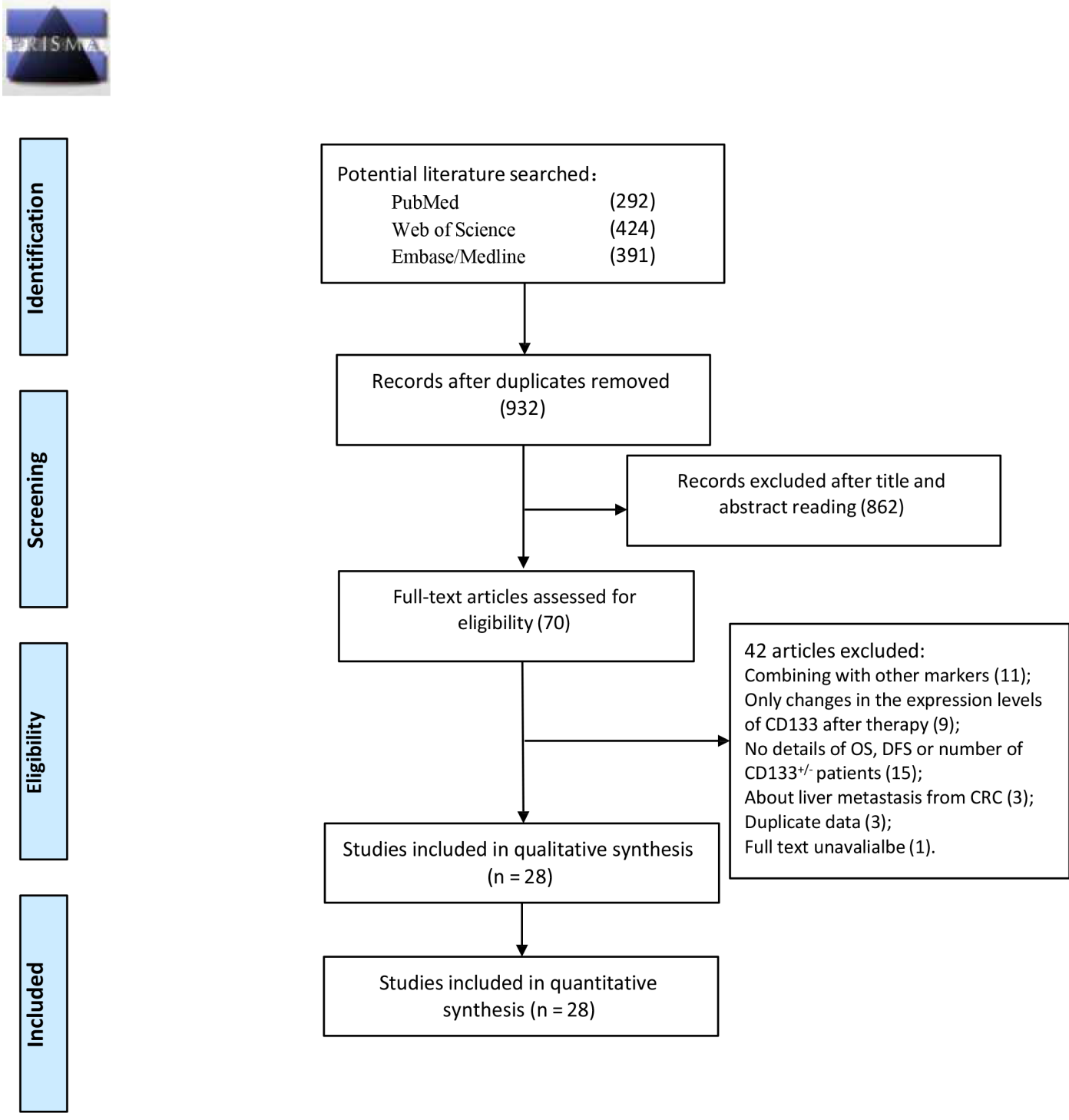

Figure 1: Flow chart for eligible articles identified in this meta-analysis. 
Table 1: Baseline characteristics of all the included studies

\begin{tabular}{|c|c|c|c|c|c|c|c|c|c|}
\hline Author & Ethnicity & Year & $\begin{array}{c}\text { Sample } \\
\text { size }\end{array}$ & Age (yr) & Location & Histology & $\begin{array}{l}\text { Research } \\
\text { techniques }\end{array}$ & Ab used & Positive standard \\
\hline Lin [52] & USA & 2007 & 66 & $61.3 \pm 13.5$ & Colon (66) & $\begin{array}{l}\text { Well (4); } \\
\text { Mod (55); } \\
\text { Poor (7) }\end{array}$ & PCR & & $\begin{array}{c}\text { CD133 mRNA } \\
\text { levels } \geq 4.79\end{array}$ \\
\hline $\begin{array}{c}\text { Kojima } \\
{[50]}\end{array}$ & Japan & 2008 & 189 & $62.1 \pm 9.7$ & $\begin{array}{l}\text { Colon (66); } \\
\text { Rectum (83) }\end{array}$ & $\begin{array}{c}\text { Well/mod } \\
\text { (160); Poor (29) }\end{array}$ & $\mathrm{IHC}$ & $\begin{array}{c}\text { anti-CD133 Ab } \\
\text { (AC133, Miltenyi } \\
\text { Biotec, })\end{array}$ & $\begin{array}{l}\text { the percentage } \\
\text { of CD133-positive } \\
\text { cells } \geq 10 \%\end{array}$ \\
\hline Choi [49] & $\begin{array}{l}\text { South } \\
\text { Korea }\end{array}$ & 2009 & 523 & $59.0(17-87)$ & $\begin{array}{l}\text { Cecum (18); } \\
\text { Colon (255); } \\
\text { Rectum (250) }\end{array}$ & $\begin{array}{l}\text { Well (23); } \\
\text { Mod (393); } \\
\text { Poor (100); } \\
\text { Un (7) }\end{array}$ & $\mathrm{IHC}$ & $\begin{array}{c}\text { Polyclonal anti-CD133 } \\
\text { Ab } \\
\text { (Santa Cruz) }\end{array}$ & cytoplasmic positivity \\
\hline Li [51] & China & 2009 & 104 & ND & Colon (104) & $\begin{array}{l}\text { Well (5); } \\
\text { Mod (80); } \\
\text { Poor (19) }\end{array}$ & $\mathrm{IHC}$ & $\begin{array}{l}\text { monoclonal anti- } \\
\text { CD133 Ab } \\
\text { (Abcam) }\end{array}$ & $\begin{array}{c}\text { the percentage } \\
\text { of CD133-positive } \\
\text { cells } \geq 5 \%\end{array}$ \\
\hline $\begin{array}{c}\text { Wang } \\
{[54]}\end{array}$ & China & 2009 & 73 & $50.2 \pm 14.1$ & Rectum (73) & $\begin{array}{l}\text { Well (5); } \\
\text { Mod (39); } \\
\text { Poor (29) }\end{array}$ & IHC & $\begin{array}{l}\text { polyclonal Ab } \\
\text { (Abcam) }\end{array}$ & $\begin{array}{l}\text { the percentage of } \\
\text { CD133-positive } \\
\text { cells } \geq 10 \%\end{array}$ \\
\hline Horst [53] & Germany & 2009 & 110 & ND & ND & $\begin{array}{l}\text { G2 (99); } \\
\text { G3 (11) }\end{array}$ & $\mathrm{IHC}$ & $\begin{array}{l}\text { monoclonal anti- } \\
\text { CD133 Ab } \\
\text { (Cell Signaling } \\
\text { Technology) }\end{array}$ & $\begin{array}{l}\text { the percentage of } \\
\text { CD133-positive } \\
\text { cells } \geq 50 \%\end{array}$ \\
\hline Huh [56] & Korea & 2010 & 61 & $64(30-78)$ & $\begin{array}{l}\text { Colon (30); } \\
\text { Rectum (31) }\end{array}$ & \begin{tabular}{|c|} 
Well $/ \bmod (53) ;$ \\
Poor (8)
\end{tabular} & PCR & & ND \\
\hline $\begin{array}{c}\text { Artells } \\
{[55]}\end{array}$ & Spain & 2010 & 64 & $70(39-88)$ & Colon (64) & A (9); B (55) & PCR & & ND \\
\hline $\begin{array}{c}\text { Kojima } \\
{[57]}\end{array}$ & Japan & 2010 & 102 & $\begin{array}{c}55.9 \pm 11.4^{*} \\
57.8 \pm 9.7 \#\end{array}$ & Rectum (102) & $\begin{array}{c}\text { Well/mod } \\
\text { (160); Poor (29) }\end{array}$ & IHC & $\begin{array}{l}\text { anti-CD133 Ab } \\
\text { (AC133; Miltenyi } \\
\text { Biotec) }\end{array}$ & $\begin{array}{l}\text { the percentage of } \\
\text { CD133-positive } \\
\text { cells } \geq 10 \%\end{array}$ \\
\hline $\begin{array}{c}\text { Takahashi } \\
\text { [59] }\end{array}$ & Japan & 2010 & 151 & $67.1(3-89)$ & $\begin{array}{l}\text { Colon (99); } \\
\text { Rectum (52) }\end{array}$ & $\begin{array}{l}\text { Well (59); } \\
\text { Mod (92) }\end{array}$ & $\mathrm{IHC}$ & $\begin{array}{l}\text { polyclonal anti- } \\
\text { CD133 Ab } \\
\text { (Abcam) }\end{array}$ & $\begin{array}{l}\text { the percentage of } \\
\text { CD133-positive } \\
\text { cells } \geq 50 \%\end{array}$ \\
\hline Ong [58] & Singapore & 2010 & 501 & ND & ND & ND & $\mathrm{IHC}$ & & $\begin{array}{l}\text { the percentage of } \\
\text { CD133-positive } \\
\text { cells } \geq 10 \%\end{array}$ \\
\hline $\mathrm{Xi}[62]$ & China & 2011 & 201 & $20-81$ & ND & $\begin{array}{l}\text { Well (24); } \\
\text { Mod (110); } \\
\text { Poor (67) }\end{array}$ & $\mathrm{IHC}$ & $\begin{array}{c}\text { polyclonal anti-CD133 } \\
\text { Ab } \\
\text { (Abcam) }\end{array}$ & $\begin{array}{c}\text { final scores } \\
\text { (multiplying the } \\
\text { intensity of positivity } \\
\text { and the extent of } \\
\text { positivity scores) } \geq 5\end{array}$ \\
\hline $\begin{array}{c}\text { Nagata } \\
\text { [61] }\end{array}$ & Japan & 2011 & 58 & ND & Rectum (58) & ND & $\mathrm{IHC}$ & $\begin{array}{c}\text { polyclonal anti-CD133 } \\
\text { Ab } \\
\text { (AC133; ABGENT) }\end{array}$ & ND \\
\hline $\begin{array}{c}\text { García } \\
\text { [60] }\end{array}$ & Spain & 2011 & 88 & $66(34-84)$ & Rectum (88) & ND & IHC & $\begin{array}{c}\text { polyclonal anti-CD133 } \\
\text { Ab } \\
\text { [AC133, Miltenyi } \\
\text { Biotec }]\end{array}$ & $\begin{array}{l}\text { the percentage of } \\
\text { CD133-positive } \\
\text { cells }>10 \%\end{array}$ \\
\hline $\begin{array}{c}\text { Zhang } \\
{[68]}\end{array}$ & China & 2012 & 125 & 61.8 & Colon (125) & $\begin{array}{l}\text { Well (14); } \\
\text { Mod (102); } \\
\text { Poor (9) }\end{array}$ & $\mathrm{IHC}$ & $\begin{array}{l}\text { monoclonal anti- } \\
\text { CD133 Ab } \\
\text { (Novus) }\end{array}$ & $\begin{array}{c}\text { index sum (totaling the } \\
\text { scores of intensity and } \\
\text { percentages) } \geq 4\end{array}$ \\
\hline Li [67] & China & 2012 & 200 & $58.1(18-85)$ & $\mathrm{CRC}$ & $\begin{array}{l}\text { Well (61); } \\
\text { Mod (93); } \\
\text { Poor (46) }\end{array}$ & $\mathrm{IHC}$ & $\begin{array}{c}\text { polyclonal anti-CD133 } \\
\text { Ab } \\
\text { (Abcam) }\end{array}$ & $\begin{array}{c}\text { final scores } \\
\text { (multiplying the } \\
\text { intensity of positivity } \\
\text { and the extent of } \\
\text { positivity scores) } \geq 4\end{array}$ \\
\hline $\begin{array}{c}\text { Bonetti } \\
{[63]}\end{array}$ & Italy & 2012 & 95 & $69.4 \pm 10.5$ & $\mathrm{CRC}$ & $\begin{array}{c}\text { Well (26); } \\
\text { Mod/poor (69) }\end{array}$ & $\mathrm{IHC}$ & $\begin{array}{c}\text { polyclonal anti-CD133 } \\
\text { Ab } \\
\text { (Santa Cruz) }\end{array}$ & $\begin{array}{l}\text { the percentage of } \\
\text { CD133-positive } \\
\text { cells } \geq 50 \%\end{array}$ \\
\hline
\end{tabular}




\begin{tabular}{|c|c|c|c|c|c|c|c|c|c|}
\hline $\begin{array}{c}\text { Hongo } \\
{[65]}\end{array}$ & Japan & 2012 & 303 & $\begin{array}{l}61.2 \pm 10.1 * \\
63.4 \pm 10.9 \#\end{array}$ & $\begin{array}{l}\text { Cecum (11); } \\
\text { Colon (234); } \\
\text { Rectum (58) }\end{array}$ & $\begin{array}{l}\text { Well (224); } \\
\text { Mod (69); } \\
\text { Poor (7); } \\
\text { Mucinous (3) }\end{array}$ & $\mathrm{IHC}$ & $\begin{array}{c}\text { primary anti-CD133 } \\
\text { Ab } \\
\text { (AC133; Miltenyi } \\
\text { Biotec) }\end{array}$ & $\begin{array}{l}\text { the percentage of } \\
\text { CD133-positive } \\
\text { cells } \geq 5 \%\end{array}$ \\
\hline Jao [66] & China & 2012 & 233 & $\begin{array}{l}57.11 \pm 5.85 \\
\quad(\leq 64) \\
83.63 \pm 5.86 \\
\quad(\geq 64)\end{array}$ & $\begin{array}{l}\text { Colon (157); } \\
\text { Rectum (76) }\end{array}$ & $\begin{array}{l}\text { Well (38); Mod/ } \\
\text { poor (195) }\end{array}$ & $\mathrm{IHC}$ & $\begin{array}{c}\text { monoclonal anti- } \\
\text { CD133 Ab } \\
\text { (clone C24B9, Cell } \\
\text { Signaling Technology) }\end{array}$ & $\begin{array}{l}\text { immunoreactivity } \\
\text { scores (the percentage } \\
\text { of CD133-positive } \\
\text { cells at each level } \\
\text { multiplied by the } \\
\text { corresponding } \\
\text { intensity) }>150\end{array}$ \\
\hline Coco [64] & Italy & 2012 & 137 & $66.8(31-86)$ & Colon (137) & $\begin{array}{l}\text { well } / \bmod (95) \\
\text { Poor (42) }\end{array}$ & $\mathrm{IHC}$ & $\begin{array}{l}\text { polyclonal anti-CD133 } \\
\text { Ab } \\
\text { (Santa Cruz) } \\
\text { monoclonal AC133 Ab } \\
\text { (Miltenyi Biotec) }\end{array}$ & $\begin{array}{l}\text { the percentage of } \\
\text { CD133-positive } \\
\text { cells } \geq 5 \%\end{array}$ \\
\hline Ying [70] & China & 2013 & 176 & $54.9 \pm 13.5$ & $\begin{array}{l}\text { Colon (109); } \\
\text { Rectum (67) }\end{array}$ & $\begin{array}{c}\text { Well/mod } \\
\text { (138); Poor (38) }\end{array}$ & $\mathrm{IHC}$ & $\begin{array}{l}\text { monoclonal anti- } \\
\text { CD133 Ab } \\
\text { (clone AC133, } \\
\text { Miltenyi Biotec) }\end{array}$ & $\begin{array}{c}\text { Using a ROC curve } \\
\text { analysis }\end{array}$ \\
\hline $\begin{array}{c}\text { Mia-Jan } \\
\text { [69] }\end{array}$ & $\begin{array}{l}\text { South } \\
\text { Korea }\end{array}$ & 2013 & 271 & $\begin{array}{c}63.166 \\
(27-101)\end{array}$ & $\begin{array}{l}\text { Colon (150); } \\
\text { Rectum (121) }\end{array}$ & $\begin{array}{l}\text { Well (16); } \\
\text { Mod (225); } \\
\text { Poor (30) }\end{array}$ & $\mathrm{IHC}$ & $\begin{array}{c}\text { anti-CD133 Ab } \\
\text { (AC133, Miltenyi } \\
\text { Biotec) }\end{array}$ & $\begin{array}{l}\text { the percentage of } \\
\text { CD133-positive } \\
\text { cells } \geq 10 \%\end{array}$ \\
\hline $\begin{array}{c}\text { Shikina } \\
\text { [72] }\end{array}$ & Japan & 2014 & 234 & ND & $\begin{array}{l}\text { Colon (88); } \\
\text { Rectum (61) }\end{array}$ & $\begin{array}{l}\text { Well/mod } \\
(129) ; \text { Poor/ } \\
\text { muc (20) }\end{array}$ & $\mathrm{IHC}$ & $\begin{array}{l}\text { anti-CD133 Ab } \\
\text { ( clone AC133) }\end{array}$ & $\begin{array}{l}\text { the percentage of } \\
\text { CD133-positive } \\
\text { cells } \geq 10 \%\end{array}$ \\
\hline $\begin{array}{c}\text { Antonio } \\
\text { Oliver } \\
{[71]}\end{array}$ & Spain & 2014 & 123 & $\begin{array}{c}71.73 \pm \\
10.57\end{array}$ & $\mathrm{CRC}$ & $\begin{array}{l}\text { Well (37); } \\
\text { Mod (59); } \\
\text { Poor (21) }\end{array}$ & $\mathrm{IHC}$ & $\begin{array}{l}\text { anti-CD133 Ab } \\
\text { ( Miltenyi Biotec) }\end{array}$ & NO \\
\hline Zhou [74] & China & 2014 & 60 & $51.6(3268)$ & $\mathrm{CRC}$ & $\begin{array}{l}\text { Well (20); } \\
\text { Mod (20); } \\
\text { Poor }(20)\end{array}$ & $\mathrm{IHC}$ & $\begin{array}{l}\text { anti-CD133 Ab } \\
\text { (EarthOx, LLC) }\end{array}$ & $\begin{array}{l}\text { the percentage of } \\
\text { CD133-positive } \\
\text { cells } \geq 20 \%\end{array}$ \\
\hline Vaz [73] & Spain & 2014 & 100 & $68(45-92)$ & Colon (100) & ND & $\mathrm{IHC}$ & $\begin{array}{l}\text { monoclonal anti- } \\
\text { CD133 Ab } \\
\text { (Cell Signaling } \\
\text { Technology) }\end{array}$ & $\begin{array}{l}\text { the percentage of } \\
\text { CD133-positive } \\
\text { cells } \geq 10 \%\end{array}$ \\
\hline Hong [75] & Korea & 2015 & 162 & $61(29-85)$ & $\begin{array}{l}\text { Colon (88); } \\
\text { Rectum (74) }\end{array}$ & $\begin{array}{l}\text { Well (19); } \\
\text { Mod (123); } \\
\text { Poor (20) }\end{array}$ & $\mathrm{IHC}$ & $\begin{array}{c}\text { anti-CD133 Ab } \\
\text { (AC133, Miltenyi } \\
\text { Biotec) }\end{array}$ & $\begin{array}{l}\text { scores of positivite } \\
\text { tumor cells } \geq 1\end{array}$ \\
\hline Jing [40] & Korea & 2015 & 36 & $66(42-91)$ & $\begin{array}{l}\text { Colon (21); } \\
\text { Rectum (15) }\end{array}$ & $\begin{array}{l}\text { Well } / \bmod (20) ; \\
\text { Poor }(15)\end{array}$ & PCR & & $\begin{array}{c}\text { CD133 mRNA levels } \\
12675\end{array}$ \\
\hline
\end{tabular}

Abbreviations: ND, no details; IHC, immunohistochemistry; PCR, polymerase chain reaction; CRC, colorectal cancer; ROC curve, receiver operator characteristic curve; mod, moderate; *subgroup with preoperative or postoperative therapy; \#subgroup with surgery alone.

lymph node micrometastases. Ying et al. suggested that low expression of CD133 in CRC primary tumors could improve survival and reduce the probability of recurrence [70]. Similarly, Bonetti et al. showed that CD133 High patients had shorter DFS and cancer-specific survival than CD133 ${ }^{\text {Low }}$ cases [63]. In contrast, Zhou et al. and Hong et al. found no significant difference between $\mathrm{CD} 133^{\text {High }}$ and $\mathrm{CD} 133^{\text {Low }}$ cases in terms of survival time in CRC patients with stage I-IV disease [74, 75]. Such contrasting results made it difficult to establish CD133 as a useful marker to adequately predict the pathological features and prognostic outcomes in clinical practice.

Based on a systematic review of previous work, we found that CD133 expression was highly correlated with poor OS and DFS, indicating that CD133+ CSCs likely have a close relationship with patient survival and tumor relapse. Among the included studies, six selected patients who received curative surgery rather than postoperative therapy (non-AT subgroup) [53, 55, 58, 63, 72, 73]. Eleven evaluated cancer survival and recurrence among patients, all or most of whom underwent both surgical and adjuvant therapy (AT subgroup) [50, 51, 55, 58, 59, 67-72]. Stratified analysis showed that in subgroups with or without AT, CD133 ${ }^{\text {High }}$ patients had poorer clinical outcomes as compared to CD133 ${ }^{\text {Low }}$ patients, indicating that the prognostic significance of CD133 expression in CRC patients was not influenced by the intervention of postoperative adjuvant therapy. 
The above findings demonstrated that CD133 level could be regarded as an independent and promising predictive factor for determining prognosis and likelihood of recurrence in colorectal cancer patients. Furthermore, after postoperative therapy, CD133 ${ }^{\text {High }}$ patients exhibited significantly poorer outcomes than CD133 $3^{\text {Low }}$ patients, indicating that CD133 ${ }^{\text {Low }}$ patients might benefit from adjuvant treatments. Thus, CD133 expression also provided a promising tool for optimizing patient-specific therapeutic strategies. CD133 ${ }^{\text {High }}$ cancer patients required further aggressive treatments or anti-CSC targeted therapy in addition to surgery and postoperative adjuvant therapy. For CD $133^{\text {Low }}$ patients, a more moderate treatment strategy could be employed.
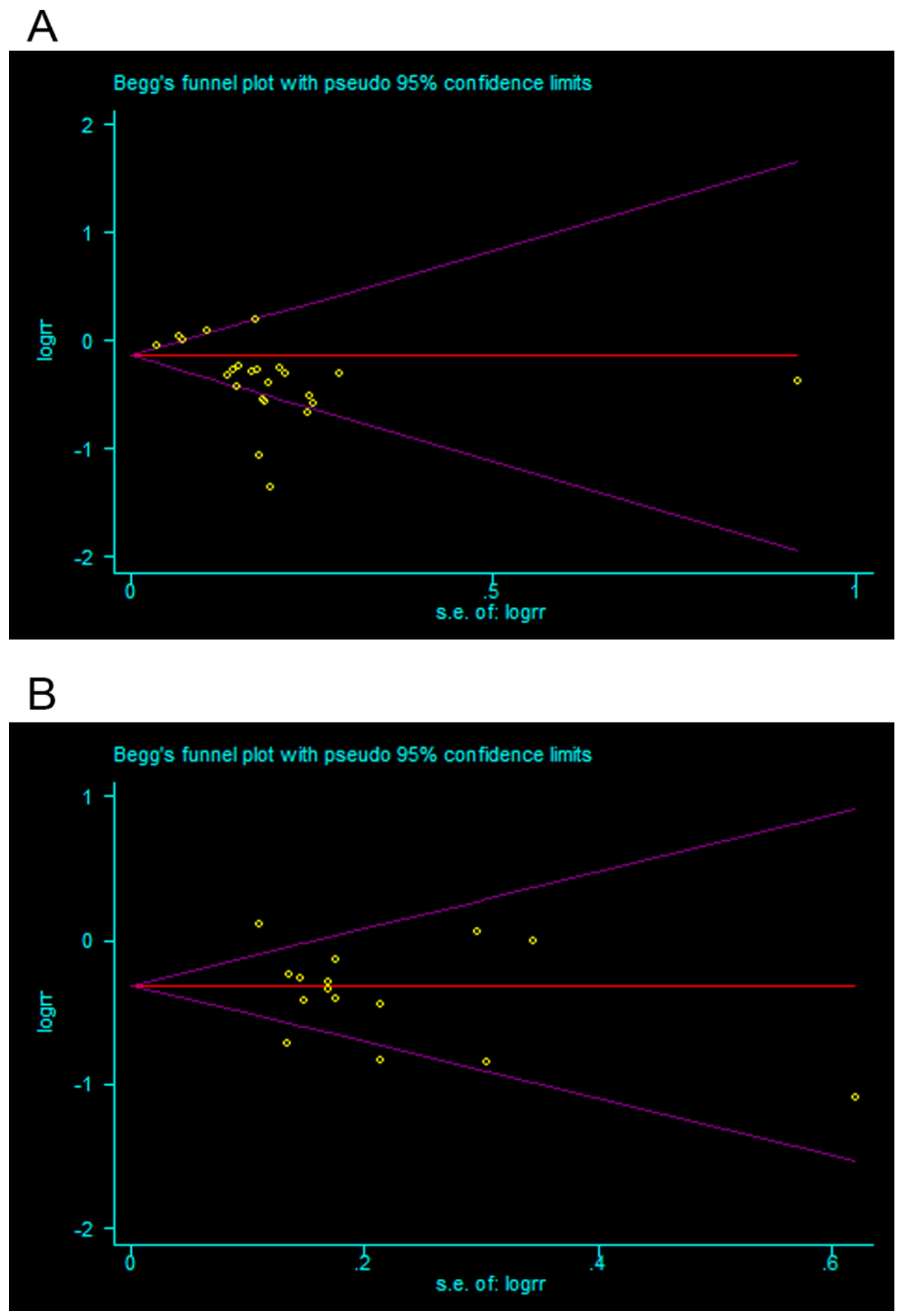

Figure 2: Begg's funnel plots to explore the possibility of publication bias in the pooled analyses of CD133 expression and OS (A) or DFS (B). 
Table 2: Results of subgroup analysis

\begin{tabular}{|c|c|c|c|c|c|c|}
\hline \multirow{2}{*}{$\begin{array}{c}\text { Comparison } \\
\text { variables }\end{array}$} & \multicolumn{3}{|c|}{ OS } & \multicolumn{3}{|c|}{ DFS } \\
\hline & $\begin{array}{c}\text { Studies } \\
\text { number }\end{array}$ & $\begin{array}{c}\text { RR } \\
(95 \% \mathrm{CI})\end{array}$ & $\begin{array}{c}P \\
\text { value }\end{array}$ & $\begin{array}{c}\text { Studies } \\
\text { number }\end{array}$ & $\operatorname{RR}(95 \% \mathrm{CI})$ & $\begin{array}{c}P \\
\text { value }\end{array}$ \\
\hline \multicolumn{7}{|l|}{ Sample size } \\
\hline$\geq 100$ & 15 & $0.703(0.586-0.842)$ & $<0.01$ & 8 & $0.749(0.615-0.913)$ & $<0.01$ \\
\hline$<\mathbf{1 0 0}$ & 8 & $0.743(0.606-0.911)$ & 0.086 & 7 & $0.635(0.483-0.834)$ & 0.077 \\
\hline \multicolumn{7}{|l|}{ Ethnicity } \\
\hline Asia & 17 & $0.705(0.591-0.840)$ & $<0.01$ & 9 & $0.740(0.586-0.933)$ & $<0.01$ \\
\hline Western countries & 6 & $0.741(0.588-0.934)$ & 0.034 & 6 & $0.669(0.572-0.782)$ & 0.531 \\
\hline \multicolumn{7}{|l|}{ Research technique } \\
\hline $\mathrm{IHC}$ & 21 & $0.716(0.613-0.836)$ & $<0.01$ & 12 & $0.697(0.575-0.846)$ & $<0.01$ \\
\hline PCR & 2 & $0.704(0.537-0.923)$ & 0.430 & 3 & $0.721(0.566-0.919)$ & 0.550 \\
\hline \multicolumn{7}{|l|}{ Therapeutic strategy } \\
\hline AT & 9 & $0.716(0.554-0.926)$ & $<0.01$ & 6 & $0.687(0.554-0.852)$ & \begin{tabular}{|l|}
0.047 \\
\end{tabular} \\
\hline Non-AT & 4 & $0.623(0.481-0.807)$ & 0.332 & 4 & $0.651(0.519-0.817)$ & 0.328 \\
\hline ND & 12 & $0.769(0.631-0.937)$ & $<0.01$ & 7 & $0.748(0.550-1.018)$ & $<0.01$ \\
\hline
\end{tabular}

\section{Evidence in support of the CSC hypothesis}

According to the CSC hypothesis, tumors are initiated and manipulated by CSCs. CSCs may resist the current therapies through a multitude of mechanisms, including the presence of activated drug-efflux transporters, increased expression of intracellular detoxification enzymes, up-regulation of anti-apoptotic proteins, and enhanced efficiency of DNA repair, as well as the influences of the tumor microenvironment [9, 27, 47, 76-78]. More than previous theories involving chromosomal abnormalities, somatic mutations and multiple mutations, which suggested tumors developed as a result of chromosomal mutations and selection of clones from groups of cells over time, the CSC hypothesis may help to clarify the physiological properties of tumors and the associated biological alterations [9]. CD133 ${ }^{\text {High }}$ patients generally have more CSCs and a smaller likelihood of eradicating these CSCs through conventional therapies than CD133 ${ }^{\text {Low }}$ patients. Successful therapy for CD133 ${ }^{\text {High }}$ patients would more likely require a combination of surgery and other complementary treatments.

Our study found that tumor relapse was positively correlated with higher CSC levels in tumors, indicating that tumor recurrence may be at least in part a result of residual CSCs persisting after surgical treatment and adjuvant therapy. Tumor initiation may also be supported by the presence of CSCs $[1,2,79-81]$. The processes of both tumor initiation and relapse could then be explained by the capacity of CSCs to proliferate uncontrolled, generate differentiated cancer cells and resist unfavorable environmental agents. However, because no currently available clinical data directly demonstrates an association between tumor initiation and CSCs, our tumor recurrence results provided only indirect evidence for the hypothesis that tumors may derive from CSCs. Thus, large-scale, prospective and direct clinical evidence is still required to further verify this hypothesis.

\section{Limitations}

Certain limitations influenced the interpretation of our results. First, this meta-analyses confirmed the prognostic value of CSCs in CRC, but the disease model was limited to CRC. Further studies are needed to investigate the role of CSCs in other kinds of cancer. Second, clinical parameters of tumors also include tumor differentiation status, tumor staging, resection rate, etc., but relevant data were so limited that we were unable to systematically estimate the association with CD133 expression state. Third, potential publication bias might exist, which could lead to an overestimation of the clinical value of CSCs. Additional relevant reports may have appeared while we completed this study.

\section{CONCLUSIONS}

In conclusion, this meta-analysis showed that a high level of the CSC marker CD133 was significantly correlated with poor DFS and OS in CRC patients. These results suggest that $\mathrm{CD} 133^{+} \mathrm{CSC}$ s might be responsible for poor prognosis and early relapses (i.e., treatment failure) in the disease model of CRC. Stratified analysis of adjuvant therapy revealed that receiving adjuvant therapy did not influence the prognoses of CRC patients with high CD133 expression, indicating that $\mathrm{CD} 133^{\text {High }}$ patients 


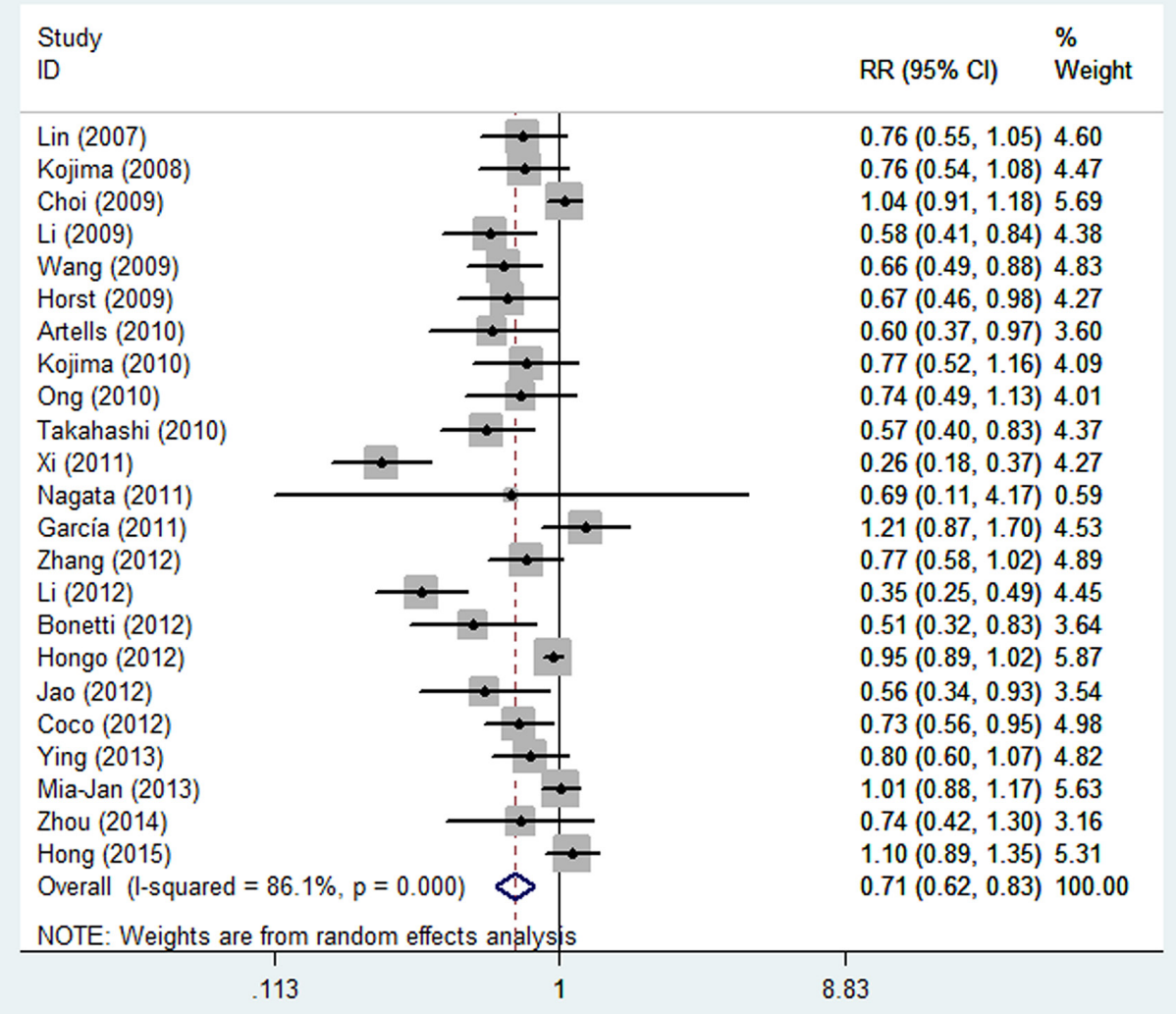

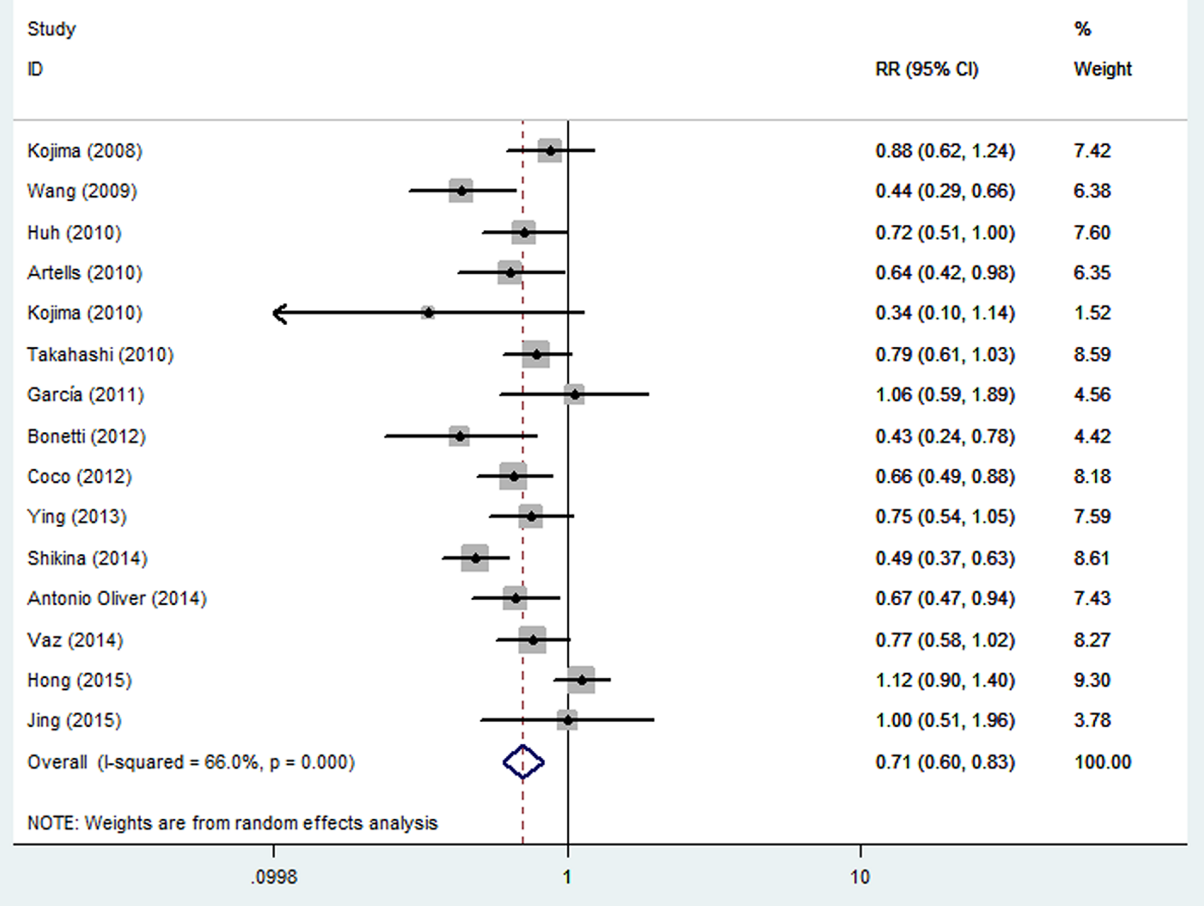

Figure 3: Forest plots of RRs for the association of CD133 expression with the (A) OS and (B) DFS. 

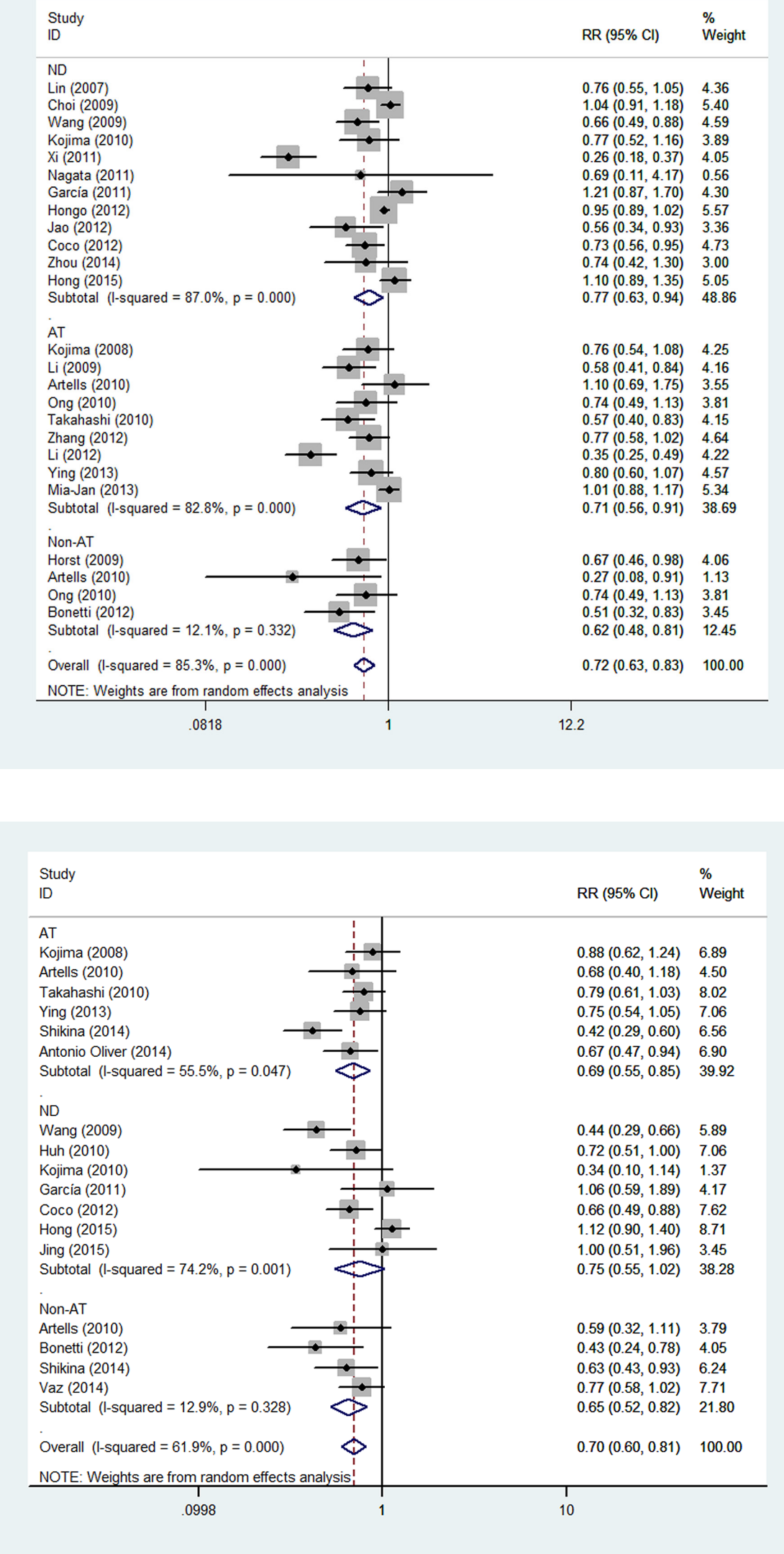

Figure 4: The stratified analysis evaluating the association of CD133 expression with (A) OS and (B) DFS in the subgroups with or without AT. 
should be given novel treatments. In the AT subgroup, CD133 ${ }^{\text {Low }}$ patients had better clinical outcomes than CD133 $3^{\text {High }}$ patients, suggesting that CD133 ${ }^{\text {Low }}$ patients could benefit from adjuvant treatments. Expanding this disease model to other kinds of cancers followed by a systematic review of additional CSC clinical data would promote further translation of the CSC hypothesis into cancer therapy. Large-scale, prospective clinical trials with advanced methodologies are still required to verify the CSC hypothesis directly.

\section{METHODS}

\section{Literature search strategy}

Published data was systematically sought in PubMed, Embase/Medline and Web of Science, with no language restrictions, using the search terms, ["cancer stem cell," "tumor-initiating cell" OR "neoplastic Stem Cells"] AND ["CD133," " prominin-1" OR "AC133"] AND ["colon cancer", "rectal cancer" OR "colorectal cancer"]. This search was regularly updated through Aug 1, 2015. The reference lists of included studies and review articles were also searched to find additional eligible studies.

\section{Study selection}

Two reviewers independently reviewed all studies and selected eligible trials. The criteria for our analysis were as follows: (1) The study must be a clinical study concerning the correlation between CSCs and clinical outcomes in patients with CRCs. (2) CRCs were diagnosed by the reference standards, histopathologic analysis. (3) CD133 expression should be evaluated in primary colorectal cancer tissue. (4) Levels of CD133 were examined using immunohistochemistry (IHC) methods, tissue microarray or PCR. (5) The data provided must be sufficient to estimate either disease free survival (DFS) or overall survival (OS). (6) All cases should have a follow-up of over 2 years. Studies that could not meet any one of the above inclusion criteria were excluded. Animal studies, review articles, letters, comments, case reports and unpublished articles were also excluded. When the authors published several studies using the same subjects, only the most recent or the publication including the largest sample size was included.

\section{Data extraction}

The full manuscripts of included articles were reviewed by three reviewers independently. Data extracted included first author's name, country of the population studied, year of publication, sample size, patient age, patient enrollment, study design, tumor site, histological grade, research technique, antibody used, positive standard, therapeutic strategy, survival outcomes and duration of follow-up. Based on characteristics of the extracted data, prognosis parameters were clarified into two groups, one group of relevant survival outcomes (including overall survival, cancer specific survival or disease specific survival) and one group of recurrence status (including recurrence free survival or disease free survival). If some articles revealed the prognosis of CRC only by Kaplan-Meier curve, the software Engauge Digitizer 4.1 (http://sourceforge.net/projects/digitizer/) was utilized to extract the relevant data. In case both the results of multivariate analysis and univariate analysis were provided, the former would be used in the meta-analysis. If the above information could not be retrieved from the original study, an email for help to find the relevant data was sent to the correspond author, or else the item was treated as "Not Documented (ND)". Any disagreements were resolved by consensus discussion.

\section{Statistical analysis}

The statistical package Stata (version 12.0) was used for this meta-analysis. In the forest plots, relative risks (RR) and their 95\% confidence intervals (CIs) were graphically displayed to assess the association between CSCs and clinical outcomes. The Cochran's Q test assessed the presence of statistical heterogeneity. $I^{2}$ test estimated the magnitude of heterogeneity. If the Q test showed a $P<0.05$ or the $I^{2}$ test exhibited $>50 \%$, indicating significant heterogeneity between studies, the random-effect model was conducted, or the fixed-effect model was used. We then performed stratified analyses based on ethnicity, research techniques (IHC or PCR), and adjuvant therapy (surgery alone or with adjuvant therapy or not documented). Sensitivity analysis was performed to assess the stability of results. Publication bias was examined by using the Begg rank correlation method and the Egger weighted regression method.

\section{ACKNOWLEDGMENTS AND FUNDING}

We would like to acknowledge the helpful comments on this paper received from our reviewers. Additionally, we would like to thank all our colleagues in the Department of Radiology, The Second Hospital of Tianjin Medical University. This work were supported by the National Natural Science Foundation of China (No: 81472682 and No: 81572538), the Tianjin Natural Science Foundation (No: 13JCYBJC23800) and Research Fund for the Doctoral Program of Higher Education (No:20131202110008). We are also deeply grateful to the following authors, who, by providing uncompensated further details on their published studies, made this analysis possible: Koji Tanaka, Department of Gastrointestinal and Pediatric Surgery, Mie University Graduate School of Medicine, Tsu, Japan; Edward H. Lin, Department of Gastrointestinal Medical Oncology, 
the University of Texas M. D. Anderson Cancer Center, Houston, Texas, USA.; Pavel Pitule, Biomedical Center, Faculty of Medicine in Pilsen, Charles University in Prague, Pilsen, Czech Republic; Heinz-Josef Lenz and Dongyun Yang, Division of Medical Oncology, University of Southern California, Los Angeles, CA, USA.

\section{CONFLICTS OF INTEREST} interests.

All authors declared that they had no conflicts of

\section{REFERENCES}

1. Reya T, Morrison SJ, Clarke MF, Weissman IL. Stem cells, cancer, and cancer stem cells. Nature. 2001; 414:105-111.

2. Nguyen LV, Vanner R, Dirks P, Eaves CJ. Cancer stem cells: an evolving concept. Nat Rev Cancer. 2012; 12:133-143.

3. Clarke MF, Dick JE, Dirks PB, Eaves CJ, Jamieson CH, Jones DL, Visvader J, Weissman IL, Wahl GM. Cancer stem cells - perspectives on current status and future directions: AACR Workshop on cancer stem cells. Cancer Res. 2006; 66:9339-9344.

4. Clevers H. The cancer stem cell: premises, promises and challenges. Nat Med. 2011; 17:313-319.

5. Al-Hajj M, Wicha MS, Benito-Hernandez A, Morrison SJ, Clarke MF. Prospective identification of tumorigenic breast cancer cells. Proc Natl Acad Sci U S A. 2003; 100:3983-3988.

6. Ricci-Vitiani L, Lombardi DG, Pilozzi E, Biffoni M, Todaro M, Peschle C, De Maria R. Identification and expansion of human colon-cancer-initiating cells. Nature. 2007; 445:111-115.

7. Geng SQ, Alexandrou AT, Li JJ. Breast cancer stem cells: Multiple capacities in tumor metastasis. Cancer Lett. 2014; 349:1-7.

8. Li S, Li Q. Cancer stem cells and tumor metastasis (Review). Int J Oncol. 2014; 44:1806-1812.

9. O’Connor ML, Xiang D, Shigdar S, Macdonald J, Li Y, Wang T, Pu C, Wang Z, Qiao L, Duan W. Cancer stem cells: A contentious hypothesis now moving forward. Cancer Lett. 2014; 344:180-187.

10. De Palma M, Venneri MA, Galli R, Sergi SL, Politi LS, Sampaolesi M, Naldini L. Tie2 identifies a hematopoietic lineage of proangiogenic monocytes required for tumor vessel formation and a mesenchymal population of pericyte progenitors. Cancer Cell. 2005; 8:211-226.

11. Quintana E, Shackleton M, Sabel MS, Fullen DR, Johnson TM, Morrison SJ. Efficient tumour formation by single human melanoma cells. Nature. 2008; 456:593-598.

12. Medema JP. Cancer stem cells: the challenges ahead. Nat Cell Biol. 2013; 15:338-344.

13. Visvader JE, Lindeman GJ. Cancer stem cells in solid tumours: accumulating evidence and unresolved questions. Nat Rev Cancer. 2008; 8:755-768.
14. Grosse-Gehling P, Fargeas CA, Dittfeld C, Garbe Y, Alison MR, Corbeil D, Kunz-Schughart LA. CD133 as a biomarker for putative cancer stem cells in solid tumours: limitations, problems and challenges. J Pathol. $2013 ; 229: 355-378$.

15. O'Brien CA, Pollett A, Gallinger S, Dick JE. A human colon cancer cell capable of initiating tumour growth in immunodeficient mice. Nature. 2007; 445:106-110.

16. Corbeil D, Roper K, Hellwig A, Tavian M, Miraglia S, Watt SM, Simmons PJ, Peault B, Buck DW, Huttner WB. The human AC133 hematopoietic stem cell antigen is also expressed in epithelial cells and targeted to plasma membrane protrusions. J Biol Chem. 2000; 275:5512-5520.

17. Miraglia S, Godfrey W, Yin AH, Atkins K, Warnke R, Holden JT, Bray RA, Waller EK, Buck DW. A novel five-transmembrane hematopoietic stem cell antigen: isolation, characterization, and molecular cloning. Blood. 1997; 90:5013-5021.

18. Zhu X, Prasad S, Gaedicke S, Hettich M, Firat E, Niedermann G. Patient-derived glioblastoma stem cells are killed by CD133-specific CAR T cells but induce the T cell aging marker CD57. Oncotarget. 2015; 6:171-184. doi: 10.18632/oncotarget.2767.

19. Li M, Zhang L, Ge C, Chen L, Fang T, Li H, Tian H, Liu J, Chen T, Jiang G, Xie H, Cui Y, Yao M, et al. An isocorydine derivative (d-ICD) inhibits drug resistance by downregulating IGF2BP3 expression in hepatocellular carcinoma. Oncotarget. 2015; 6:25149-25160. doi: 10.18632/oncotarget.4438.

20. Bostad M, Olsen CE, Peng Q, Berg K, Hogset A, Selbo PK. Light-controlled endosomal escape of the novel CD133-targeting immunotoxin AC133-saporin by photochemical internalization - A minimally invasive cancer stem cell-targeting strategy. J Control Release. 2015; 206:37-48.

21. Zhang L, Li H, Ge C, Li M, Zhao FY, Hou HL, Zhu MX, Tian H, Zhang LX, Chen TY, Jiang GP, Xie HY, Cui Y, et al. Inhibitory effects of transcription factor Ikaros on the expression of liver cancer stem cell marker CD133 in hepatocellular carcinoma. Oncotarget. 2014; 5:10621-10635. doi: 10.18632/oncotarget.2524.

22. Gaedicke S, Braun F, Prasad S, Machein M, Firat E, Hettich M, Gudihal R, Zhu X, Klingner K, Schuler J, Herold-Mende CC, Grosu AL, Behe M, et al. Noninvasive positron emission tomography and fluorescence imaging of CD133+ tumor stem cells. Proc Natl Acad Sci U S A. 2014; 111:E692-701.

23. Chai S, Tong M, Ng KY, Kwan PS, Chan YP, Fung TM, Lee TK, Wong N, Xie D, Yuan YF, Guan XY, Ma S. Regulatory role of miR-142-3p on the functional hepatic cancer stem cell marker CD133. Oncotarget. 2014; 5:5725-5735. doi: 10.18632/oncotarget.2167.

24. Swaminathan SK, Roger E, Toti U, Niu L, Ohlfest JR, Panyam J. CD133-targeted paclitaxel delivery inhibits local tumor recurrence in a mouse model of breast cancer. J Control Release. 2013; 171:280-287. 
25. Allegra A, Alonci A, Penna G, Innao V, Gerace D, Rotondo F, Musolino C. The Cancer Stem Cell Hypothesis:A Guide to Potential Molecular Targets. Cancer Invest. 2014; 32:470-495.

26. Cheng JX, Liu BL, Zhang X. How powerful is CD133 as a cancer stem cell marker in brain tumors? Cancer Treat Rev. 2009; 35:403-408.

27. Vidal SJ, Rodriguez-Bravo V, Galsky M, Cordon-Cardo C, Domingo-Domenech J. Targeting cancer stem cells to suppress acquired chemotherapy resistance. Oncogene. 2014; 33:4451-4463.

28. Singh SK, Hawkins C, Clarke ID, Squire JA, Bayani J, Hide T, Henkelman RM, Cusimano MD, Dirks PB. Identification of human brain tumour initiating cells. Nature. 2004; 432:396-401.

29. Iinuma H, Watanabe T, Mimori K, Adachi M, Hayashi N, Tamura J, Matsuda K, Fukushima R, Okinaga K, Sasako M, Mori M. Clinical significance of circulating tumor cells, including cancer stem-like cells, in peripheral blood for recurrence and prognosis in patients with dukes' stage B and C colorectal cancer. J Clin Oncol. 2011; 29:1547-1555.

30. Mehra N, Penning M, Maas J, Beerepoot LV, van Daal N, van Gils $\mathrm{CH}$, Giles RH, Voest EE. Progenitor marker CD133 mRNA is elevated in peripheral blood of cancer patients with bone metastases. Clin Cancer Res. 2006; 12:4859-4866.

31. Wang K, Xu J, Zhang J, Huang J. Prognostic role of CD133 expression in colorectal cancer: a meta-analysis. BMC Cancer. 2012; 12:573.

32. Wen L, Chen XZ, Yang K, Chen ZX, Zhang B, Chen JP, Zhou ZG, Mo XM, Hu JK. Prognostic Value of Cancer Stem Cell Marker CD133 Expression in Gastric Cancer: A Systematic Review. PLoS One. 2013; 8:e59154.

33. Chen S, Song X, Chen Z, Li X, Li M, Liu H, Li J. CD133 expression and the prognosis of colorectal cancer: a systematic review and meta-analysis. PLoS One. 2013; 8:e56380.

34. Wu S, Yu L, Wang D, Zhou L, Cheng Z, Chai D, Ma L, Tao Y. Aberrant expression of CD133 in non-small cell lung cancer and its relationship to vasculogenic mimicry. BMC Cancer. 2012; 12:535.

35. Arne G, Kristiansson E, Nerman O, Kindblom LG, Ahlman H, Nilsson B, Nilsson O. Expression profiling of GIST: CD133 is associated with KIT exon 11 mutations, gastric location and poor prognosis. Int J Cancer. 2011; 129:1149-1161.

36. Ma YH, Mentlein R, Knerlich F, Kruse ML, Mehdorn HM, Held-Feindt J. Expression of stem cell markers in human astrocytomas of different WHO grades. J Neurooncol. 2008; $86: 31-45$.

37. Zhao P, Lu Y, Jiang X, Li X. Clinicopathological significance and prognostic value of CD133 expression in triple-negative breast carcinoma. Cancer Sci. 2011; 102:1107-1111.
38. Chen YC, Hsu HS, Chen YW, Tsai TH, How CK, Wang CY, Hung SC, Chang YL, Tsai ML, Lee YY, Ku HH, Chiou SH. Oct-4 expression maintained cancer stem-like properties in lung cancer-derived CD133-positive cells. PLoS One. 2008; 3:e2637.

39. Salnikov AV, Gladkich J, Moldenhauer G, Volm M, Mattern J, Herr I. CD133 is indicative for a resistance phenotype but does not represent a prognostic marker for survival of non-small cell lung cancer patients. Int J Cancer. 2010; 126:950-958.

40. Jing F, Kim HJ, Kim CH, Kim YJ, Lee JH, Kim HR. Colon cancer stem cell markers CD44 and CD133 in patients with colorectal cancer and synchronous hepatic metastases. Int J Oncol. 2015; 46:1582-1588.

41. Shien K, Toyooka S, Ichimura K, Soh J, Furukawa M, Maki Y, Muraoka T, Tanaka N, Ueno T, Asano H, Tsukuda K, Yamane M, Oto T, et al. Prognostic impact of cancer stem cell-related markers in non-small cell lung cancer patients treated with induction chemoradiotherapy. Lung Cancer. 2012; 77:162-167.

42. Zhai J-H, Gu W-C, Xu X-L, Wu J, Hu X-J, Hou K-Z. Prognostic value of CD133 expression in cancer patients treated with chemoradiotherapy: a meta-analysis. Tumor Biol. 2015; 36:701-709.

43. Siegel R, Naishadham D, Jemal A. Cancer Statistics, 2012. Ca-Cancer J Clin. 2012; 62:10-29.

44. Tan IB, Malik S, Ramnarayanan K, McPherson JR, Ho DL, Suzuki Y, Ng SB, Yan S, Lim KH, Koh D, Hoe CM, Chan CY, Ten R, et al. High-depth sequencing of over 750 genes supports linear progression of primary tumors and metastases in most patients with liver-limited metastatic colorectal cancer. Genome Biol. 2015; 16.

45. Cunningham D, Atkin W, Lenz HJ, Lynch HT, Minsky B, Nordlinger B, Starling N. Colorectal cancer. Lancet. 2010; 375:1030-1047.

46. Kruschewski M, Ciurea M, Lipka S, Daum S, Moser L, Meyer B, Grone J, Budczies J, Buhr HJ. Locally recurrent colorectal cancer:results of surgical therapy. Langenbecks Arch Surg. 2012; 397:1059-1067.

47. Colak S, Medema JP. Cancer stem cells — important players in tumor therapy resistance. FEBS J. 2014; 281:4779-4791.

48. Fanali C, Lucchetti D, Farina M, Corbi M, Cufino V, Cittadini A, Sgambato A. Cancer stem cells in colorectal cancer from pathogenesis to therapy:controversies and perspectives. World J Gastroenterol. 2014; 20:923-942.

49. Choi D, Lee HW, Hur KY, Kim JL, Park G-S, Jang S-H, Song YS, Lang K-S, Paik SS. Cancer stem cell markers CD133 and CD24 correlate with invasiveness and differentiation in colorectal adenocarcinoma. World $\mathrm{J}$ Gastroenterol. 2009; 15:2258-2264.

50. Kojima M, Ishii G, Atsumi N, Fujii S, Saito N, Ochiai A. Immunohistochemical detection of CD133 expression in colorectal cancer: A clinicopathological study. Cancer Sci. 2008; 99:1578-1583. 
51. Li CY, Li BX, Liang Y, Peng RQ, Ding Y, Xu DZ, Zhang X, Pan ZZ, Wan DS, Zeng YX, Zhu XF, Zhang XS. Higher percentage of CD133+ cells is associated with poor prognosis in colon carcinoma patients with stage IIIB. J Transl Med. 2009; 7:56.

52. Lin EH, Hassan M, Li Y, Zhao H, Nooka A, Sorenson E, Xie K, Champlin R, Wu X, Li D. Elevated circulating endothelial progenitor marker CD133 messenger RNA levels predict colon cancer recurrence. Cancer. 2007; 110:534-542.

53. Horst D, Kriegl L, Engel J, Kirchner T, Jung A. Prognostic significance of the cancer stem cell markers CD133, CD44, and CD166 in colorectal cancer. Cancer Invest. 2009; 27:844-850.

54. Wang Q, Chen Z-G, Du C-Z, Wang H-W, Yan L, Gu J. Cancer stem cell marker CD133+ tumour cells and clinical outcome in rectal cancer. Histopathology. 2009; 55:284-293.

55. Artells R, Moreno I, Diaz T, Martinez F, Gel B, Navarro A, Ibeas R, Moreno J, Monzo M. Tumour CD133 mRNA expression and clinical outcome in surgically resected colorectal cancer patients. Eur J Cancer. 2010; 46:642-649.

56. Huh JW, Park YS, Lee JH, Kim HR, Shin MG, Kim YJ. CD133 mRNA expression and microsatellite instability in colorectal carcinoma. J Surg Oncol. 2010; 102:765-770.

57. Kojima M, Ishii G, Atsumi N, Nishizawa Y, Saito N, Ochiai A. CD133 expression in rectal cancer after preoperative chemoradiotherapy. Cancer Sci. 2010; 101:906-912.

58. Ong CW, Kim LG, Kong HH, Low LY, Iacopetta B, Soong R, Salto-Tellez M. CD133 expression predicts for nonresponse to chemotherapy in colorectal cancer. Mod Pathol. $2010 ; 23: 450-457$.

59. Takahashi S, Kamiyama T, Tomaru U, Ishizu A, Shida T, Osaka M, Sato Y, Saji Y, Ozaki M, Todo S. Frequency and pattern of expression of the stem cell marker CD133 have strong prognostic effect on the surgical outcome of colorectal cancer patients. Oncol Rep. 2010; 24:1201-1212.

60. García VM, Batlle JF, Casado E, Burgos E, de Castro J, Belda C, Barriuso J, Sánchez JJ, García-Cabezas MÁ, González-Barón M, Cejas P. Immunohistochemical analysis of tumour regression grade for rectal cancer after neoadjuvant chemoradiotherapy. Colorectal Dis. 2011; 13:989-998.

61. Nagata T, Sakakura C, Komiyama S, Miyashita A, Nishio M, Murayama Y, Komatsu S, Shiozaki A, Kuriu Y, Ikoma H, Nakanishi M, Ichikawa D, Fujiwara H, et al. Expression of cancer stem cell markers CD133 and CD44 in locoregional recurrence of rectal cancer. Anticancer Res. 2011; 31:495-500.

62. Xi HQ, Zhao P. Clinicopathological significance and prognostic value of EphA3 and CD133 expression in colorectal carcinoma. J Clin Pathol. 2011; 64:498-503.

63. Bonetti LR, Migaldi M, Caredda E, Boninsegna A, De Leon MP, Di Gregorio C, Barresi V, Scannone D, Danese S, Cittadini A, Sgambato A. Increased expression of CD133 is a strong predictor of poor outcome in stage I colorectal cancer patients. Scand J Gastroenterol. 2012; 47:1211-1217.
64. Coco C, Zannoni GF, Caredda E, Sioletic S, Boninsegna A, Migaldi M, Rizzo G, Bonetti LR, Genovese G, Stigliano E, Cittadini A, Sgambato A. Increased expression of CD133 and reduced dystroglycan expression are strong predictors of poor outcome in colon cancer patients. J Exp Clin Cancer Res. 2012; 31:71.

65. Hongo K, Kazama S, Sunami E, Tsuno NH, Takahashi K, Nagawa H, Kitayama J. Immunohistochemical detection of CD133 is associated with tumor regression grade after chemoradiotherapy in rectal cancer. Med Oncol. 2012; 29:2849-2857.

66. Jao SW, Chen SF, Lin YS, Chang YC, Lee TY, Wu CC, Jin JS, Nieh S. Cytoplasmic CD133 Expression is a Reliable Prognostic Indicator of Tumor Regression After Neoadjuvant Concurrent Chemoradiotherapy in Patients with Rectal Cancer. Ann Surg Oncol. 2012:1-9.

67. Li H, Zhao P, Lu Y, Lu Y. Correlation of aberrant expression of CD133 with FHIT and malignant phenotype of colorectal adenocarcinoma. Int J Colorectal Dis. 2012; 27:1015-1020.

68. Zhang NH, Li J, Li Y, Zhang XT, Liao WT, Zhang JY, Li R, Luo RC. Co-expression of CXCR4 and CD133 proteins is associated with poor prognosis in stage II-III colon cancer patients. Exp Ther Med. 2012; 3:973-982.

69. Mia-Jan K, Jung SY, Kim IY, Oh SS, Choi E, Chang SJ, Kang TY, Cho MY. CD133 expression is not an independent prognostic factor in stage II and III colorectal cancer but may predict the better outcome in patients with adjuvant therapy. BMC cancer. 2013; 13:166.

70. Ying X, Wu J, Meng X, Zuo Y, Xia Q, Chen J, Feng Y, Liu R, Li L, Huang W. AC133 expression associated with poor prognosis in stage II colorectal cancer. Med Oncol. 2013; 30.

71. Oliver JA, Ortiz R, Melguizo C, Alvarez PJ, GomezMillan J, Prados J. Prognostic impact of MGMT promoter methylation and MGMT and CD133 expression in colorectal adenocarcinoma. BMC Cancer. 2014; 14:511.

72. Shikina A, Shinto E, Hashiguchi Y, Ueno H, Naito Y, Okamoto K, Kubo T, Fukazawa S, Yamamoto J, Hase K. Differential clinical benefits of 5-fluorouracil-based adjuvant chemotherapy for patients with stage III colorectal cancer according to CD133 expression status. Jpn J Clin Oncol. 2014; 44:42-48.

73. Vaz MA, Martinez JC, Devesa JM, Trill JD, Abraira V, Riquelme A, Carrato A. Prognostic Value of Stem Cell Quantification in Stage II Colon Cancer. PLoS One. 2014; 9(e884802).

74. Zhou F, Mu Y-D, Liang J, Liu Z-X, Chen H-S, Zhang J-F. Expression and prognostic value of tumor stem cell markers ALDH1 and CD133 in colorectal carcinoma. Oncol Lett. 2014; 7:507-512.

75. Hong I, Hong SW, Chang YG, Lee WY, Lee B, Kang YK, Kim YS, Paik IW, Lee H. Expression of the Cancer Stem Cell Markers CD44 and CD133 in Colorectal Cancer: An Immunohistochemical Staining Analysis. 2015; 31:84-91. 
76. Alison MR, Lin WR, Lim SM, Nicholson LJ. Cancer stem cells: in the line of fire. Cancer Treat Rev. 2012; 38:589-598.

77. Dean M, Fojo T, Bates S. Tumour stem cells and drug resistance. Nat Rev Cancer. 2005; 5:275-284.

78. Tanabe A, Deguchi T, Sato T, Nemoto Y, Maruo T, Madarame H, Shida T, Naya Y, Ogihara K, Sahara H. Radioresistance of cancer stem-like cell derived from canine tumours. Vet Comp Oncol. 2014.

79. Delude C. Tumorigenesis Testing ground for cancer stem cells. Nature. 2011; 480:S43-S45.
80. Vicente-Duenas C, Hauer J, Ruiz-Roca L, Ingenhag D, Rodriguez-Meira A, Auer F, Borkhardt A, Sanchez-Garcia I. Tumoral stem cell reprogramming as a driver of cancer: Theory, biological models, implications in cancer therapy. Semin Cancer Biol. 2014.

81. White AC, Lowry WE. Refining the role for adult stem cells as cancer cells of origin. Trends Cell Biol. 2015; 25:11-20. 